\title{
PENILAIAN KEEFEKTIFAN KELOMPOK DISKUSI TUTORIAL MAHASISWA KEDOKTERAN UNIVERSITAS JAMBI MENGGUNAKAN TUTORIAL GROUP EFFECTIVENESS INSTRUMENT
}

\author{
Nyimas Natasha A Shafira, Amelia Dwi Fitri \\ Faculty of Medicine and Health Sciences Jambi University \\ Email : nyimasnatasha@gmail.com
}

\begin{abstract}
Background: Tutorial is one of the learning methods that is used in the implementation of Problem Based Learning $(P B L)$ in the medical education. The effectiveness of PBL tutorial discussions is influenced by three basic aspects, i.e. students, tutors, and scenario. The effectiveness of the group tutorial must be ensured because it determines the success of PBL learning in medical education.

Research Objective : This study aims to look at the effectiveness of tutorials groups discussion on medical students at the Faculty of Medicine and Health Sciences University of Jambi (FKIK UNJA) based on students' perceptions.

Method : This research is a combination of quantitative research and qualitative research. Quantitative research conducted was a cross sectional study using, using the Tutorial Group Effectiveness Instrument (TGEI) questionnaire. The use of the TGEI questionnaire in this study was to find out the effectiveness of tutorials groups discussion on FKIK UNJA medical students based on students' perceptions. Furthermore, qualitative research was conducted with focus group discussions (FGD) to confirm and explore students' perceptions based on the results of the questionnaire analysis.

Results : Overall, based on the cognitive, motivational and demotivational aspects, the majority of the effectiveness of tutorial discussion of medical students of FKIK, belongs to moderate category (>95\%) based on student perceptions.
\end{abstract}

Conclusion : The results of the study show that the tutorial discussion of medical students of FKIK UNJA was going quite efficient and effective.

Keywords : PBL, tutorials, medical students, TGEI

ABSTRAK

Latar Belakang: Tutorial merupakan salah satu metode pembelajaran yang digunakan dalam pelaksanaan Problem Based Learning (PBL) di pendidikan kedokteran. Keefektifan diskusi tutorial PBL 
dipengaruhi oleh tiga aspek dasar yaitu, mahasiswa, tutor, dan skenario. Keefektifan kelompok tutorial harus dipastikan karena menentukan kesuksesan pembelajaran PBL di pendidikan kedokteran.

Tujuan Penelitian: Penelitian ini bertujuan untuk melihat keefektifan kelompok diskusi tutorial pada mahasiswa kedokteran Fakultas Kedokteran dan IImu Kesehatan Universitas Jambi (FKIK UNJA) berdasarkan persepsi mahasiswa

Metode: Penelitian ini merupakan gabungan antara penelitian kuantitatif dan penelitian kualitatif. Penelitian kuantitatif yang dilakukan merupakan, studi cross sectional dengan menggunakan kuesioner Tutorial Group Effectiveness Instrument (TGEI). Penggunaan kuesioner TGEI pada penelitian ini untuk mengetahui gambaran keefektifan kelompok diskusi tutorial pada mahasiswa kedokteran FKIK UNJA berdasarkan persepsi mahasiswa. Selanjutnya dilakukan penelitian kualitatif dengan diskusi kelompok terfokus (DKT) untuk mengkonfirmasi dan mengeksplorasi persepsi mahasiswa tersebut berdasarkan hasil analisis kuesioner

Hasil: Secara keseluruhan dari segi aspek kognitif, motivasi dan demotivational, berdasarkan persepsi mahasiswa , kefektifan diskusi tutorial mahasiswa kedokteran FKIK masuk dalam kategori sedang (>95\%). Kesimpulan: Hasil penelitian menunjukkan diskusi tutorial mahasiswa kedokteran FKIK UNJA sudah berjalan cukup baik dan efektif.

Kata kunci: PBL, tutorial, mahasiswa kedokteran, TGEI

\section{Pendahuluan}

Kurikulum Berbasis Kompetensi adalah kurikulum yang diterapkan pada pendidikan kedokteran di Indonesia. Berdasarkan Standar Pendidikan Kedokteran Indonesia, kurikulum ini dilaksanakan dengan pendekatan/strategi Student-centred, Problem-based, Integrated, Community-based, Elective, Systematic/Structured (SPICES). (1)

Penerapan strategi atau
pendekatan model SPICES dalam kurikulum dimaksudkan untuk membentuk lulusan yang memenuhi standar kompetensi sebagai seorang dokter yang mampu memenuhi kebutuhan masyarakat. Baik tidaknya penerapan model SPICES dalam kurikulum pendidikan kedokteran akan mempengaruhi kualitas lulusan dari suatu institusi. Salah satu Penerapan model SPICES ini dilakukan dengan menggunakan metode pembelajaran Problem Based Learning (PBL) dalam proses pembelajaran (1)

Metode pembelajaran PBL saat ini sudah sangat luas digunakan di dunia, khususnya di Fakultas Kedokteran. PBL sendiri diperkenalkan oleh Howard Barrows sejak tahun 1969 di Fakultas Kedokteran McMaster, Kanada. PBL adalah sebuah strategi pembelajaran yang menitikberatkan pembelajaran pada mahasiswa atau dengan kata lain pembelajaran berpusat pada mahasiswa (student centered 
learning), dimana mahasiswa dihadapkan pada suatu masalah dalam kehidupan nyata, kemudian dari masalah tersebut mahasiswa dirangsang untuk mempelajarinya berdasarkan pengetahuan dan pengalaman yang telah mereka miliki sebelumnya (prior knowledge) sehingga dari prior knowledge ini akan terbentuk pengetahuan dan pengalaman baru. . $(2,3)$

Tutorial merupakan wujud dari terlaksananya program PBL. Kemandirian mahasiswa menjadi prinsip kegiatan tutorial. Diskusi kelompok tutorial menyebabkan terjadinya interaksi antar mahasiswa dan diharapkan terjadinya proses pembelajaran aktif (active learning). Pembelajaran aktif pada dasarnya merupakan salah satu bentuk atau jenis dari pendekatan pembelajaran yang berorientasi pada aktivitas peserta didik. Peserta didik bertanggung jawab terhadap pembelajarannya sendiri dengan terlibat dalam diskusi tutorial tersebut. $(4,5)$

Beberapa faktor yang mempengaruhi keberhasilan tutorial yaitu kinerja tutor, kualitas skenario, interaksi dalam pembelajaran kolaboratif, serta motivasi dan kognitif yang dimiliki mahasiswa tersebut. Keefektifan kelompok diskusi tutorial PBL dapat meningkatkan kemampuan mahasiswa dalam memecahkan masalah. Keterampilan dalam memecahkan masalah menjadi modal penting untuk seorang dokter saat menghadapi kasus nyata pada pasien. Keefektifan kelompok tutorial harus dipastikan karena menentukan kesuksesan pembelajaran PBL. $(6,7)$
Menurut Edmuns, Keefektifan kelompok tutorial dapat diperbaiki dengan mengobservasi proses interaksi dalam kelompok. Keefektifan diskusi tutorial PBL dipengaruhi oleh tiga aspek dasar yaitu, mahasiswa, tutor, dan skenario. Beberapa penelitian menyimpulkan kefektifan kelompok tutorial dipengaruhi jumlah anggota kelompok. ${ }^{(8)}$ Selain itu keefektifan suatu kelompok diskusi tutorial PBL juga dipengarahi oleh tiga aspek yaitu kognitif, motivasi dan demotivational dari mahasiswa. ${ }^{(9)}$

\section{Metode}

Penelitian ini merupakan gabungan antara penelitian kuantitatif dan penelitian kualitatif. Penelitian kuantitatif yang telah dilakukan merupakan penelitian kuantitatif deskriptif non eksperimental, studi cross sectional dengan menggunakan kuesioner Tutorial Group Effectiveness Instrument (TGEI). Penggunaan kuesioner TGEI pada penelitian ini untuk mengetahui gambaran keefektifan kelompok diskusi tutorial pada mahasiswa kedokteran FKIK UNJA berdasarkan persepsi mahasiswa. Selanjutnya dilakukan penelitian kualitatif dengan diskusi kelompok terfokus (DKT) untuk mengkonfirmasi dan mengeksplorasi persepsi mahasiswa tersebut berdasarkan hasil analisis kuesioner

\section{Hasil}

Pengumpulan data penelitian dilaksanakan dengan memakai kuesioner Tutorial Group Effectiveness Instrument (TGEI) kepada mahasiswa semester 3, 5 dan 7 tahun ajaran 2019/2020. Jumlah 
mahasiswa yang bersedia mengisi kuesioner adalah 314 orang.

Data penelitian yang diperoleh dianalisis secara univariat dengan menggunakan program statistik. Hasil penelitian ini menyajikan gambaran distribusi frekuensi dari berbagai aspek diantaranya aspek kognitif, motivasi, demotivational untuk menggambarkan bagaimana persepsi mahasiswa terhadap keefektifan kelompok diskusi tutorial pada Mahasiswa Kedokteran FKIK UNJA .

\section{Gambaran Keefektifan Diskusi Tutorial Mahasiswa Program Studi Kedokteran FKIK UNJA}

Tabel 1 Distribusi Frekuensi Gambaran Keefektifan Kelompok Diskusi Tutorial Mahasiswa Kedokteran FKIK UNJA

\begin{tabular}{lcccccccc}
\hline \multicolumn{1}{c}{ Aspek } & \multicolumn{2}{c}{ Rendah } & \multicolumn{2}{c}{ Sedang } & \multicolumn{2}{c}{ Tinggi } & \multicolumn{2}{c}{ Total } \\
& $\mathrm{N}$ & $\%$ & $\mathrm{~N}$ & $\%$ & $\mathrm{~N}$ & $\%$ & $\mathrm{~N}$ & $\%$ \\
\hline Keefektifan & 9 & 2,87 & 302 & 96,18 & 3 & 0,96 & 314 & 100 \\
Kognitif & 11 & 3,50 & 303 & 96,18 & 1 & 0,32 & 314 & 100 \\
Motivasi & 7 & 2,23 & 305 & 97,13 & 2 & 0,64 & 314 & 100 \\
Demotivational & 9 & 2,87 & 303 & 96,50 & 2 & 0,64 & 314 & 100 \\
\hline
\end{tabular}

Berdasarkan Tabel 1 didapatkan distribusi frekuensi nilai ketiga aspek (kognitif, motivasi, dan demotivational) dari 314 Mahasiswa Kedokteran FKIK UNJA. Hasil analisa menurut persepsi mahasiswa terhadap keefektifan kelompok diskusi tutorial secara keseluruhan pada Mahasiswa Kedokteran FKIK UNJA yaitu paling banyak terdapat dalam kategori sedang (96,18\%). Dari segi aspek kognitif, motivasi dan demotivational pada diskusi tutorial mahasiswa kedokteran FKIK paling banyak masuk dalam kategori sedang.

\section{Gambaran Keefektifan Diskusi Tutorial Mahasiswa Semester 3 Program Studi Kedokteran FKIK UNJA}

Tabel 2 Distribusi Frekuensi Gambaran Keefektifan Kelompok Diskusi Tutorial Mahasiswa Kedokteran semester 3 FKIK UNJA

\begin{tabular}{|c|c|c|c|c|c|c|c|c|}
\hline \multirow[t]{2}{*}{ Aspek } & \multicolumn{2}{|c|}{ Rendah } & \multicolumn{2}{|c|}{ Sedang } & \multicolumn{2}{|c|}{ Tinggi } & \multicolumn{2}{|c|}{ Total } \\
\hline & $\mathrm{N}$ & $\%$ & $\mathrm{~N}$ & $\%$ & $\mathrm{~N}$ & $\%$ & $\mathrm{~N}$ & $\%$ \\
\hline Keefektifan & 3 & 2,54 & 114 & 96,61 & 1 & 0,85 & 118 & 100 \\
\hline Kognitif & 5 & 4,24 & 112 & 96,92 & 1 & 0,85 & 118 & 100 \\
\hline Motivasi & 2 & 1,69 & 116 & 98,31 & 0 & 0 & 118 & 100 \\
\hline Demotivational & 0 & 0 & 116 & 98,31 & 2 & 1,69 & 118 & 100 \\
\hline
\end{tabular}

Berdasarkan Tabel 2 didapatkan distribusi frekuensi nilai ketiga aspek (kognitif, motivasi, dan demotivational) dari 118 Mahasiswa Kedokteran semester 3 
FKIK UNJA. Hasil analisa menurut persepsi mahasiswa terhadap keefektifan kelompok diskusi tutorial secara keseluruhan pada mahasiswa Kedokteran FKIK UNJA yaitu paling banyak terdapat dalam kategori sedang (96,61\%). Dari segi aspek kognitif , motivasi dan demotivational pada diskusi tutorial mahasiswa kedokteran semester 3 FKIK UNJA paling banyak masuk dalam kategori sedang.

\section{Gambaran Keefektifan Diskusi Tutorial Mahasiswa Semester 5 Program Studi Kedokteran FKIK UNJA}

Tabel 3 Distribusi Frekuensi Gambaran Keefektifan Kelompok Diskusi Tutor Mahasiswa Kedokteran semester 5 FKIK UNJA

\begin{tabular}{lcccccccc}
\hline \multicolumn{1}{c}{ Aspek } & \multicolumn{2}{c}{ Rendah } & \multicolumn{2}{c}{ Sedang } & \multicolumn{2}{c}{ Tinggi } & \multicolumn{2}{c}{ Total } \\
& $\mathrm{N}$ & $\%$ & $\mathrm{~N}$ & $\%$ & $\mathrm{~N}$ & $\%$ & $\mathrm{~N}$ & $\%$ \\
\hline Keefektifan & 3 & 3,09 & 93 & 95,88 & 1 & 1,03 & 97 & 100 \\
Kognitif & 2 & 2,06 & 95 & 97,94 & 0 & 0 & 97 & 100 \\
Motivasi & 2 & 2,06 & 94 & 96,91 & 1 & 1,03 & 97 & 100 \\
Demotivational & 4 & 4,12 & 93 & 95,88 & 0 & 0 & 97 & 100 \\
\hline
\end{tabular}

Berdasarkan Tabel 3 didapatkan distribusi frekuensi nilai ketiga aspek (kognitif, motivasi, dan demotivational) dari 97 Mahasiswa Kedokteran semester 5 FKIK UNJA. Hasil analisa menurut persepsi mahasiswa terhadap keefektifan kelompok diskusi tutorial secara keseluruhan pada
Mahasiswa Kedokteran FKIK UNJA yaitu paling banyak terdapat dalam kategori sedang (95,88\%). Dari segi aspek kognitif, motivasi dan demotivational pada diskusi tutorial mahasiswa kedokteran semester 5 FKIK UNJA paling banyak masuk dalam kategori sedang.

\section{Gambaran Keefektifan Diskusi Tutorial Mahasiswa Semester 7 Program Studi Kedokteran FKIK UNJA}

Tabel 4 Distribusi Frekuensi Gambaran Keefektifan Kelompok Diskusi Tutor Mahasiswa Kedokteran semester 7 FKIK UNJA

\begin{tabular}{lcccccccc}
\hline \multicolumn{1}{c}{ Aspek } & \multicolumn{2}{c}{ Rendah } & \multicolumn{2}{c}{ Sedang } & \multicolumn{2}{c}{ Tinggi } & \multicolumn{2}{c}{ Total } \\
& $\mathrm{N}$ & $\%$ & $\mathrm{~N}$ & $\%$ & $\mathrm{~N}$ & $\%$ & $\mathrm{~N}$ & $\%$ \\
\hline Keefektifan & 3 & 3,03 & 95 & 95,96 & 1 & 1,01 & 99 & 100 \\
Kognitif & 3 & 3,03 & 96 & 96,97 & 0 & 0 & 99 & 100 \\
Motivasi & 3 & 3,03 & 95 & 95,96 & 1 & 1,01 & 99 & 100 \\
Demotivational & 5 & 5,05 & 94 & 94,95 & 0 & 0 & 99 & 100 \\
\hline
\end{tabular}

Tabel 4 didapatkan distribusi frekuensi nilai ketiga aspek (kognitif, motivasi, dan demotivational) dari 97 Mahasiswa Kedokteran semester 7 FKIK
UNJA. Hasil analisa menurut persepsi mahasiswa terhadap keefektifan kelompok diskusi tutorial secara keseluruhan pada Mahasiswa Kedokteran FKIK UNJA yaitu 
paling banyak terdapat dalam kategori sedang (95,96\%). Dari segi aspek kognitif, motivasi dan demotivational pada diskusi tutorial mahasiswa kedokteran semester 7 FKIK UNJA paling banyak masuk dalam kategori sedang.

Dari hasil analisis univariat, aspek demotivational pada diskusi kelompok tutorial mahasiswa kedokteran termasuk dalam kategori sedang. Hal ini menunjukkan pada diskusi tutorial, menurut persepsi mahasiswa aspek demotivational masih sering terjadi. Penelitian dilanjutkan melalui diskusi kelompok terfokus untuk membahas aspek demotivational yang masih sering terjadi.

Berdasarkan hasil diskusi kelompok terfokus yang membahas aspek demotivational, untuk aspek demotivational "Selama berlangsungnya tutorial, beberapa anggota kelompok hanya berkontribusi sedikit dalam diskusi kelompok". Menurut mahasiswa hal ini masih sering terjadi pada diskusi tutorial dan penyebabnya juga banyak. Kemungkinan penyebabnya antara lain dikarenakan anggota kelompok tersebut tidak mempersiapkan diri belajar saat tutor, merasa tidak percaya diri, kondisi kesehatan yang tidak baik dan sifat individual mahasiswa itu sendiri yang cenderung pendiam sehingga sulit berkontribusi pada diskusi kelompok.

Mahasiswa juga mengemukakan pada diskusi masih ada "Beberapa anggota kelompok secara sengaja menyimpan informasi yang mereka dapatkan selama belajar mandiri". Hal ini mungkin disebabkan karena ada mahasiswa yang sifatnya egois dan ingin terlihat menonjol saat diskusi. Tetapi bisa juga disebabkan karena mahasiswa tersebut berpikir anggota kelompoknya sudah mengetahui informasi yang dia miliki.

Untuk aspek demotivational, "Saya

tidak berkontribusi sebanyak yang saya bisa terhadap diskusi kelompok tutorial". Menurut mahasiswa hal ini bisa terjadi karena mahasiswa tersibut tidak maksimal belajar sehingga tidak siap untuk diskusi, mahasiswa tidak percaya diri, dan mungkin tidak fokus dalam diskusi karena memikirkan tugas lain yang belum diselesaikan.

Menurut mahasiswa, dalam diskusi kelompok "Beberapa anggota kelompok memberi pengaruh negatif terhadap kontribusi anggota kelompok lainnya". Hal ini masih sering terjadi, karena ada beberapa anggota kelompok yang bersikap pasif dan tidak aktif dalam diskusi sehingga dapat mempengaruhi temannya untuk ikut bersikap pasif. Mahasiswa juga mengemukakan, anggota kelompok yang terlalu dominan dan ingin menonjol sendiri dapat membuat temannya menjadi tidak pecaya diri dan cenderung untuk diam saat diskusi.

$$
\text { Dan "Beberapa anggota }
$$

kelompok membiarkan (menyerahkan) kepada anggota lainnya untuk mengerjakan tugas kelompok" merupakan aspek demotivational yang masih terjadi dalam diskusi tutorial mahasiswa kedokteran FKIK UNJA. Menurut mahasiswa hal ini terjadi karena ada beberapa anggota kelompok yang beralasan malas, tidak percaya diri, dalam 
mengerjakan tugas sehingga temannya terpaksa menyelesaikan tugas tersebut. Tetapi ada juga dikarenakan mahasiswa tersebut sakit sehingga meminta bantuan temannya dalam mengerjakan tugas tersebut.

\section{Pembahasan}

Berdasarkan hasil penelitian didapatkan bahwa persepsi mahasiswa terhadap keefektifan kelompok diskusi tutorial sebagian besar (> 90\%) berada dalam tingkat sedang. Hal ini menunjukkan diskusi tutorial mahasiswa kedokteran FKIK UNJA sudah berjalan cukup baik dan efektif. Penelitian ini sejalan dengan penelitian yang yang dilakukan oleh Virgin E Pioh dkk di Fakultas Kedokteran Universitas Sam Ratulangi didapatkan hasil bahwa keefektifan diskusi kelompok tutorial PBL di kampus tersebut sebagian besar baik. ${ }^{(6)}$

Berdasarkan hasil penelitian, terlihat bahwa sebagian besar mahasiswa kedokteran FKIK UNJA memiliki motivasi yang sedang. Motivasi adalah suatu energi yang bersumber dari dalam diri yang membangkitkan, mengarahkan dan memberikan kekuatan untuk tetap berada pada arah tersebut kepada individu dalam mencapai suatu tujuan. Motivasi adalah faktor yang penting karena hal tersebut merupakan faktor internal yang mendorong mahasiswa untuk belajar. Dengan adanya motivasi belajar yang kuat dalam diri mahasiswa dapat mendorong mahasiswa untuk lebih semangat dalam belajar sehingga mahasiswa dapat lebih mudah menguasai materi pembelajaran. ${ }^{(10-12)}$
Diskusi tutorial merupakan bentuk spesifik dari pembelajaran kolaboratif. Menurut Slavin yang disitasi oleh Dolmans, dalam pembelajaran kolaboratif menekankan pentingnya anggota kelompok mendorong temannya untuk mengerahkan upaya maksimal, dimana setiap anggota kelompok saling memotivasi dalam pelaksanaan diskusi karena setiap anggota hanya dapat mencapai tujuan pribadinya jika kelompok tersebut berhasil mencapai tujuannya. ${ }^{(13)}$

Aspek kognitif memiliki peran penting dalam pembelajaran tutorial PBL. Dari hasil penelitian didapatkan sebagian besar mahasiswa memiliki aspek kognitif cukup baik. Elaborasi kognitif memegang peranan penting dalam diskusi tutorial, elaborasi kognitif terjadi ketika anggota kelompok saling menjawab pertanyaan. Salah satu cara elaborasi yang paling efektif adalah dengan menjelaskan materi kepada satu sama lain, umpan balik, dan dengan menghubungkan informasi baru dengan pengetahuan sebelumnya. Interaksi di antara anggota kelompok, seperti diskusi, mengemukakan dan mendengarkan pendapat satu sama lain, memainkan peran penting dalam pembelajaran mahasiswa. Melalui umpan balik dan debat, rekan sejawat memotivasi satu sama lain untuk menyelesaikan kesalahpahaman dan mencari solusi yang lebih baik. ${ }^{(14)}$

Dolmans membandingkan kelompok tutorial yang tidak berhasil, cukup berhasil dan sangat berhasil berdasarkan aspek motivasi dan kognitif. Hasilnya yaitu terdapat hubungan linier antara 
keberhasilan tutorial dengan aspek motivasi dan kognitif .(13)

Berdasarkan persepsi mahasiswa, aspek demotivational pada mahasiswa kedokteran FKIK masih dalam kategori sedang. Hal ini menunjukkan bahwa pada diskusi tutorial masih sering terjadi perilaku yang bersifat demotivational. Aspek demotivational memberikan aspek negatif terhadap motivasi dan keberhasilan kelompok. Berdasarkan penelitian yang dilakukan oleh De Grave dkk mengenai 36 kejadian ktritis yang terjadi pada diskusi tutorial, faktor ketidakseimbangan dalam partisipasi merupakan faktor yang paling sering dialami, namun faktor yang dianggap paling menghambat diskusi dan sangat memerlukan intervensi tutor adalah pada faktor kurangnya motivasi. (15)

Pembelajaran kolaboratif melatih mahasiswa bekerjasama dalam kelompoknya untuk mencapai tujuan pembelajaran. Anggota kelompok bersamasama bertanggung jawab sepenuhnya atas pembelajaran yang mereka laksanakan. Dengan demikian keberhasilan kelompok ditentukan oleh usaha dari setiap anggota kelompok itu sendiri.(6) Slavin menekankan pentingnya kohesif atau kekompakan pada suatu kelompok diskusi. Ide ini menyiratkan bahwa suatu kelompok diharapkan dapat mengembangkan semangat tim kelompoknya masing-masing. Mahasiswa membantu rekan kelompok mereka karena mereka ingin kelompoknya berhasil. Dalam hal ini peran tutor juga sangat penting, tutor harus terlatih dengan baik dalam menstimulasi interaksi positif antar anggota kelompok dan dalam membangkitkan semangat tim kelompok disikusi tutoral tersebut. ${ }^{(13)}$

\section{Kesimpulan}

Berdasarkan hasil penelitian, dapat disimpulkan kegiatan diskusi tutorial mahasiswa kedokteran FKIK UNJA telah berjalan cukup baik dan efektif berdasarkan persepsi mahasiswa.

\section{Daftar Pustaka}

1. KKI. Standar kompetensi dokter. Jakarta: Konsil Kedokteran Indonesia. 2012.

2. Barrows H TR. Problem-based Learning : An Approach to Medical Education. . New York: Springer Publishing; 1980.

3. Secondaria V.M.R, G.R. Rahayu, Suhono Y. Faktor-faktor yang mempengaruhi mahasiswa fakultas kedokteran UGM untuk melaksanakan pembelajaran yang konstruktif, mandiri, kolaboratif dan kontekstual dalam problem-based learning. Jurnal Pendidikan Kedokteran Indonesia 2009.

4. McCoy L, Pettit RK, Kellar C, Morgan C. Tracking Active Learning In Medical School Curriculum : A Learning Centred Approach. Journal Of Medical Education and Curricullar Development. 2018;5.

5. Margaret Wolff M, Mary Jo Wagner, MD, Stacey Poznanski, DO,Jocelyn Schiller, MD, and Sally Santen, MD, PHD. Not another boring lecture: engaging learners with active learning techniques. 2015. 2015;4(1).

6. Pioh VE, Mewo Y, Berhimpon S. Efektivitas kelompok diskusi tutorial problem based learning di Fakultas Kedokteran Univeritas Sam Ratulangi. Jurnal e-Biomedik. 2016;4(1).

7. Fitri AD, Harsono, Suryadi E. Persepsi Mahasiswa dan Tutor tentang Kejadian Kritis Selama Diskusi Tutorial dan Jenis-jenis Intervensi Tutor terhadap Kejadian Tersebut. Jurnal Pendidikan Kedokteran Indonesia. 2012;2(3).

8. Edmunds S, Brown G. Effective Small Group Learning. AMEE Guide N0.48. Medical Teacher. 2010;32(9):715-26.

9. Singaram VS, Vleuten CPMVD, Berkel HV, Dolmans DHJM. Reliability and Validity of a Tutorial Group Effectiveness Instrument. Medical Teacher. 2010;32(3).

10. Sardiman. Interaksi dan Motivasi Belajar Mengajar. Jakarta: Rajagrafindo Persada; 2011. 
11. Uno HB. Teori Motivasi dab pengukurannya. Jakarta: Bumi Aksara; 2012.

12. Anggraini IS. Motivasi Belajar dan Faktor - Faktor yang Berpengaruh: sebuah Kajian pada Interaksi Pembelajaran Mahasiswa. Premiere Educandum: Jurnal Pendidikan Dasar dan Pembelajaran. 2011.

13. Dolmans DHJM, Wolfhagen IHAP, Vleuten CPMVD. Motivational and Cognitif Processes Influecing Tutorial Groups. Academic Medicine. 1998;73(10).

14. Dolmans DHJM, Schmidt HG. What do we Know About Cognitive and Motivational Effects of Small Group Tutorial in Probelem-Based Learning? Advances in health sciences education. 2006;11.

15. Degrave WS, Dolmans DH, Vleuten CPVD. Student Perspective on critical incidents in the tutorial group. Advances in health sciences education. 2002;7(3). 